\title{
Cellulases and Hemicellulases, why we need so much of these Enzymes?
}

\section{Marli Camassola*}

Universityof Caxias do Sul, Institute of Biotechnology, Caxias do Sul, Rio Grande do Sul, Brazil

We are increasingly dependent on energy to power the various sectors of our economy. However, we hear more and more that fossil fuels are finite and their use contributes to global warming [1]. In this sense, alternative energy sources must be developed. An inexhaustible source of great potential for power generation is lignocellulose.

Lignocellulose, a major component of plant biomass produced through photosynthesis, is abundant, sustainable and renewable. Therefore, it is no surprise that lignocellulosic bioenergy has become a subject of intense investigation. In comparison to fossil fuels, lignocellulosic biofuel offers many advantages: it is renewable and environmentally friendly; it has potential to mitigate global warming; it can prevent fuel shortage and it has no effect in the food chain. Lignocellulosic bioenergy is mainly obtained by hydrolysis of forest wastes, agricultural residues, hardwood, softwood and grasses, and subsequent fermentation of resultant hydrolysates into biofuels [2], such as second generation ethanol, biohydrogen or butanol.

One of the processes studied for obtaining the highest potential of sugars for the production of biofuel is the enzymatic hydrolysis of lignocellulosic wastes, using cellulases and hemicellulases.

The enzyme complex of cellulases comprises endoglucanases (EC 3.2.1.4) that hydrolyse internal bonds at random positions of cellulose. These enzymes generate chain ends for the processive action of the second type of cellulases, the cellobiohydrolases (which are exoglucanases). These enzymes act in a unidirectional manner from either the non-reducing (EC 3.2.1.91) or the reducing (EC 3.2.1.176) ends of cellulose polysaccharide chains, liberating cellobiose as the major product. B-d-glucosidases (EC 3.2.1.21) further hydrolyse cellobiose to glucose. The hemicellulases, a diverse group of enzymes that hydrolyse hemicelluloses are endo- $\beta-1,4$-xylanase (E.C. 3.2.1.8), exo- $\beta$-1,4-xylosidase (E.C. 3.2.1.37), $\alpha$-L-arabinofuranosidase (E.C. 3.2.1.55), endo- $\alpha-1,5$-arabinanase (E.C. 3.2.1.99), $\alpha$-glucuronidase
(E.C. 3.2.1.139), endo- $\beta-1,4$-mannanase (E.C. 3.2.1.78), exo- $\beta$ 1,4-mannosidase (E.C. 3.2.1.25), $\alpha$-galactosidase (E.C. 3.2.1.22), $\beta$-glucosidase (E.C. 3.2.1.21), endo-galactanase (E.C. 3.2.1.89), acetyl xylan esterase (E.C. 3.1.1.72), acetyl mannan esterase (E.C. 3.1.1.6), and ferulic and $\rho$-cumaric acid esterases (E.C. 3.1.1.73).

One of the biggest challenges in the process of enzymatic hydrolysis of lignocellulosic materials is the development of economically viable technologies for the production of enzymes.

Second generation ethanol needs large quantities of enzymes; it is estimated that the enzyme cost per gallon of ethanol produced is about US $\$ 0.03$ to 0.04 . Currently launching a new product the cost of second generation ethanol down to US $\$ 2$ to $\$ 2.50$ a gallon, in line with gasoline and corn ethanol. However, these values are not good enough, since ethanol produced with sugar cane has a lower price in comparison to corn ethanol.

To further reduce costs is necessary to create more efficient production processes, developing microorganisms with a greater catalytic potential and able to produce larger amounts of enzymes. For these factors, the knowledge of the producing microorganisms' physiology is essential. Other alternatives include the production of the enzymes in situ or in-house, in addition to the optimisation of production processes by means of instrumentation and automation. The fact is that we need alternative energy sources, and cellulases and hemicellulases play a key role in the future energy supply in our planet.

\section{References}

1. Somerville C, Youngs H, Taylor C, Davis SC, Long SP (2010) Feedstocks for Lignocellulosic Biofuels. Science 329: 790-792.

2. Adav SS, Chao LT, Sze SK (2012) Quantitative secretomic analysis of Trichoderma reesei strains reveals enzymatic composition for lignocellulosic biomass degradation. Mol Cell Proteomics.
*Corresponding author: Dr. Marli Camassola, Laboratoryof Enzymes and Biomass, 1130, Francisco Getúlio Vargas Street, Caxias do Sul, Rio Grande do Sul, 95070 560, Brazil, Tel: 555432182100 Ext: 2681; Fax: 55543218 2149; E-mail: macamassola@gmail.com

Received May 09, 2012; Accepted May 10, 2012; Published May 12, 2012

Citation: Camassola M (2012) Cellulases and Hemicellulases, why we need so much of these Enzymes? Ferment Technol 1:e112. doi:10.4172/21677972.1000 e112

Copyright: ( 2012 Camassola M. This is an open-access article distributed under the terms of the Creative Commons Attribution License, which permits unrestricted use, distribution, and reproduction in any medium, provided the original author and source are credited. 